\title{
How I almost killed my mother in childbirth.
}

\section{Michelle Hammer}

J'avais sept ans lorsque je suis tombée de bicyclette et que j'ai couru à la maison en saignant. Ma mère s'est exclamée: "Oh, mon Dieu ! oh, mon Dieu " et ses yeux se sont exorbités à la vue de mon sang. Ma mère avait du mal avec les accidents, à cause de son expérience dans le camp de concentration d'Auschwitz. Me raconter des histoires était une façon de m'apaiser. C'est pour ça qu'elle me raconta comment je l'avais presque tuée à ma naissance. "Tu étais en retard de deux semaines, ditelle, et le médecin dit à ton père qu'il ne pouvait en sauver qu'une seule de nous deux. Ton père décida de sauver sa jeune femme et la vie de $l^{\prime}$ enfant à venir. Le médecin, un sacré athée, déclara que c'était un miracle de Dieu que nous ayons survécu toutes les deux. " Ma mère me répéta souvent cette histoire, dessinant pour moi le cercle infernal du sang et de la féminité.

The summer I turned seven I rode the bike my father bought for me on a pebbled path in the playground of our apartment building. When I fell off my bike the pebbles dug deep into my face and knees and soon the blood dripped on the sharp white and grey pebbles. I abandoned my new bike on the side of the gravel road, not checking for damage, but rushed home, leaving a bloody trail behind, like Hansel and Gretl's breadcrumbs in the wild forest. The sight of my unfortunate accident drew the attention of the children in the playground and they followed me, pointing at my bloodied body, their voices filling the air in a cacophony of questions.

"What happened to you?"

"Who pushed you?"

I sobbed, but kept walking, ignoring their questions.

"She fell off her new bike," one girl shouted. "I saw it all."

In front of our building the children stopped and turned to find a new item of interest, while I climbed to the fourth floor.

I opened the door, looking around the apartment. Noise rose from the kitchen, a chopping knife banging on a wooden board, a familiar sound of my mother dicing onions or slicing peppers for the Sabbath meal. I closed the door behind me and sneaked into the bathroom. I 
didn't want to be noticed. Not just yet. Not until I cleaned the blood off my face and knees.

"You are home?" my mother called out from the shrine of pots and pans. "Why don't you answer me?"

My mother did not cope well with emergencies. The sight of blood, or an open wound, drove her into a state of panic. I imagined this was the result of her time in Auschwitz, something we didn't discuss often.

I started to wash the blood off my face with a hand towel, but fresh rivulets of blood dripped slowly over my face and I had to start over again. My mother appeared at the door, her eyes wide as she stood frozen, like Lot's wife. Oh, my god, oh, my god, and her eyes almost popped out, mouth open, like the fish that swam in our bathtub every week. Suddenly she took two wide steps toward me, grabbing the towel out of my hands. I almost fell backwards into the bathtub, where two carp swam back and forth before their makeover into gefilte fish.

"I knew I shouldn't have let you ride THAT BIKE," my mother hissed while trying to stop the bleeding, pressing on the bloodied gashes with the wet towel.

"Ouch, it hurts," I moaned.

"Be still," she warned, "or you'll lose all your blood, like I did when I gave birth to you."

I looked in the mirror and saw a clown's face with a red nose and red blotches, and started to cry.

"Why are you crying?"

"I look like a monster! I'll never be able to go outside again."

Mother started to laugh. I didn't appreciate her making light of my situation.

"You need to take a bath," she said.

"What! With the fish?"

"No, silly, without the fish."

When Mother attempted to catch the slippery carp, its tail shook in a furious frenzy. When she finally caught the squirming fish, she held it tightly inside her apron, hugging it like a baby. She had to place both fish in the small kitchen sink, and I imagined the carp flying in the air, like dolphins in a movie I had once seen. What if they landed in the pot of chicken soup, I worried, playing the scene in my mind, but not telling my mother any of this as she cleaned the bathtub for my bath. 
Mother knelt on the hard floor and rubbed the tub with a scouring pad and a cleanser smelling of sharp Ammonia, moaning about the delay in cooking for the Friday night meal, and why did you ride your bike today of all days?

"It's going to smell of fish," I groaned when Mother finally got up and motioned for me to undress.

"Don't be silly, we do this every week," she said.

When I didn't budge, she relented and gave the tub one more scrubbing with an extra sprinkling of Ammonia cleanser and let the water wash over the tub's surface a long time before filling it up for my bath.

My mother had her cooking schedule planned and she managed to feed the four of us without help and work six days a week. The cooking was done from scratch, without the occasional relief from a delicatessen or a fast food counter. On Wednesdays she started cooking the chicken soup and meat dishes for Friday night. She also bought the two carp on Shenkin Street and left them in the tub overnight. On Thursday night she made gefilte fish. She baked that night too, two loaves of Hungarian cakes, one filled with crushed walnuts, the other with cinnamon and raisins.

The aroma of cinnamon and yeast rose from the kitchen, warm and enticing, filling the apartment with a reminder of the sweetness of the Sabbath. I slumped in the weightlessness of my warm bath. Mother scrubbed my legs with a yellow sponge, trying to erase my injuries. She washed the blood off my face, and I squirmed as she applied stinging alcohol with a cotton ball. tub.

"Ima, stop," I shouted, splashing water over the rim of the bath-

"It's for your own good," she said with a firm hand.

At times like this Mother resorted to story-telling, her favorite educational tool. She had a story for every occasion and I loved listening to her stories because it was the only time I had my mother's attention all to myself.

"Did I ever tell you about the blood transfusion?" she asked, trying to divert my mind from my smarting bruises on my skin that felt as though I fell into a field of broken glass.

I didn't answer right away. She never waited for an answer.

"The day I gave birth to you I lost a lot of blood and almost died. You were two weeks overdue," my mother continued to scrub my 
wounded knees, her voice fluctuating with the demands of the story line. "The doctor in Sziget told your father - 'I can save only one. Which one will it be?"

My miraculous beginning was cloaked in my mother's blood and my father's love for his unborn child. Every family has a story, like a legend that shapes the lives of its people, and the story that shaped my life was the way I almost killed my mother at birth.

"Your father said, 'I want both.' When asked, 'How will you do that?' your father moved me to a large hospital in Kluj and after finding the best doctor he presented him with large bills of money. It was after the war, don't forget, people didn't have a lot of money, but your father's business flourished and he made a lot of money when most Jews were still in D.P. camps and without a penny to their name."

"What happened next?" I asked, while my mother got up to fetch a towel. I knew the story well, but my favorite part was coming up. I dried my aching body. The towel, stiff from hanging outside on the line, felt like sandpaper scraping my bruises. Mother continued her story in the kitchen, while attending to her pots and pans. She cooked chicken soup and chicken paprikash for the Friday night meal, but continued telling the blood transfusion story in a voice that rose above the bubbling pots.

"You were stuck to the walls of my uterus," Mother laughed, "almost as if you didn't want to leave my belly."

I didn't laugh, just wondered how I could be so mischievous and naughty before my birth.

"Your father was praying in the hallway and the nurse came to tell me how worried he looked."

Mother decided to sit down, as though the story was too heavy to tell while standing up. She stopped to catch her breath before rising to a crescendo: "I could hear the doctor shouting for a blood transfusion. The nurses panicked when they could not find the proper needles. The doctor yelled at the nurses, how could they not prepare the right needles and the blood. Oh, my god, can you imagine how frightened I had been when I heard his loud voice shouting, 'blood transfusion, blood transfusion.'

Every time my mother told this part of the story of my birth, her voice got loud and excited, throwing me into a state of fear and confusion. I had no idea how a child is born, but the word 'blood' created 
an image of red pools gushing out of my mother's belly, and my tiny body swimming out, like a fish, sucking air, trying to float above the red sea of blood.

"What happened then?" I asked my mother, who got up to taste the chicken soup.

"First, I closed my eyes and prayed to the souls of my mother and father who perished in Auschwitz."

"And then?"

"Well, that's when they asked your father to give blood. In those days you had to ask relatives to give blood when you went in for an operation. When you came out of my womb, the doctor said to the nurses, 'God gave birth to this baby, not I.'"

"Why?"

Mother added the punch line:

"This was a miracle," she said. "The doctor was a sworn atheist before your birth, but when it was over, he realized how close to death I had been, and while witnessing this miracle he became a believer in God's power."

In the days following my birth my mother never held me, except for the obligatory breast feedings, but my father cradled me in his arms, rocking me to sleep with the lullaby from "IL TROVATORE," which he sang to me in lieu of my mother's arms. On the fourth day after giving birth to me, my mother woke up in the middle of the night, and since no one was around, she scratched the tiny brown mole off the tip of my nose and accepted me into her life.

Later that evening, when Father returned from work, he saw my swollen face and red bruises, he turned pale, and asked my mother in a hushed voice what had happened to me.

"It's the bike you bought for her," Mother answered in a loud and accusatory voice. "I told you she doesn't need a bike."

"All children ride bikes."

"Not in this house," she said.

"You can't keep her from living a normal life," he said. "We're not living in the ghetto."

"How do you know about those days," she exclaimed, "when you haven't been to Auschwitz."

I wished my father had spoken up to defend himself, but he always retreated. His silence, like negative space in a painting, created uncertainty about the way I would perceive him as a man. 
Father, what did you do during the war?-I'll tell you when you are all grown up.

How will I know I'm all grown-up? - Don't worry, I'll remind you. My father never revealed his survival story. My mother depicted my birth on many occasions, with the same passion as that first time, drawing me into the circle of womanhood and blood. 